\title{
Research Paper Relationship between the profile characteristics of homestead vegetable growers with the extent of knowledge and rate of adoption
}

\author{
- Vani Chandran and Bindu Podikunju
}

See end of the paper for authors' affiliations

Correspondence to :

Vani Chandran Department of Agricultural Extension, College of Agriculture, Vellayani (Kerala) India

Paper History :

Received : 29.06.2019;

Revised : 05.07.2019;

Accepted : 07.08.2019
ABSTRACT : The productivity from homesteads may vary based on the effective adoption process, which can only be achieved if farmers had sufficient awareness and knowledge on different cultivation practices. The scale of knowledge and rate of adoption of various vegetable production practices may vary from person to person. Their personal characteristic has a significant role on the acceptance and adoption of a practice. Hence, the present study was conducted in the randomly selected 120 homesteads in Kollam district to understand the relationship between the profile characteristics of homestead vegetable growers with their extent of knowledge and rate of adoption of vegetable production practices. This will help the extension workers and policy makers to formulate new policies based on their profile characteristics. From the analysis conducted it was found that among the selected independent variables education and economic motivation were positively and significantly correlated to scale of knowledge at 5 per cent. Whereas the variables, experience in vegetable cultivation, extension agency contact, information seeking behaviour, social participation and training were positively and significantly correlated to scale of knowledge at 1 per cent level of significance.Among independent variables of occupational status, economic motivation, family labour utilization were positively and significantly correlated to extent of adoption at 5 per cent. Whereas the variables experience in vegetable cultivation, extension agency contact, information seeking behaviour, social participation, and training were significantly correlated to extent of adoption at 1 per cent.

KEY WORDS : Correlation, Profile characteristics, Homestead vegetable growers, Scale of knowledge, Rate of adoption

How To Cite This PAper : Chandran, Vani and Podikunju, Bindu (2019). Relationship between the profile characteristics of homestead vegetable growers with the extent of knowledge and rate of adoption. Internat. Res. J. Agric. Eco. \& Stat., 10 (2) : 215-220, DOI : 10.15740/HAS/IRJAES/10.2/215-220. Copyright@ 2019: Hind Agri-Horticultural Society. 